\title{
Faktor Motivasi Eksternal Yang Menentukan Prestasi Belajar Mahasiswa Pada Sistem Pendidikan Jarak Jauh
}

\author{
Anfas $^{1}$, Raden Sudarwo ${ }^{2}$, Umikalsum Arfa ${ }^{3}$ \\ ${ }^{1,2}$ Universitas Terbuka, Indonesia, ${ }^{3}$ Universitas Khairun, Indonesia \\ e-mail: Anfas_st_mm@ecampus.ut.ac.id
}

\begin{abstract}
Penelitian ini bertujuan untuk mengetahui faktor motivasi eksternal yang berpengaruh pada prestasi belajar mahasiswa, yakni peran orang tua, peran tutor dan peran teman sekelas dalam memberikan motivasi terhadap prestasi belajar mahasiswa. Sampel dalam penelitian ini adalah seluruh mahasiswa penerima beasiswa bidikmisi dan CSR di UPBJJ-UT Ternate sebanyak 44 mahasiswa. Uji hipotesis penelitian menggunakan analisis regresi berganda. Hasilnya menunjukkan bahwa : 1) Peran orang tua sebagai faktor motivasi ekternal, tidak berpengaruh signifikan terhadap prestasi belajar mahasiswa penerima beasiswa bidikmisi dan CSR di UPBJJ-UT Ternate; 2) Peran tutor sebagai faktor motivasi ekternal, berpengaruh positif dan signifikan terhadap prestasi belajar mahasiswa penerima beasiswa bidikmisi dan CSR di UPBJJ-UT Ternate; 3) Peran teman sekelas sebagai faktor motivasi ekternal, berpengaruh negatif dan signifikan terhadap prestasi belajar mahasiswa penerima beasiswa bidikmisi dan CSR di UPBJJ-UT Ternate.

Keywords: Pendidikan Jarak Jauh, Motivasi Ekternal, Orang Tua, Tutor, Teman Sekelas, Prestasi Belajar
\end{abstract}

\section{PENDAHULUAN}

Prestasi belajar merupakan hasil yang dicapai peserta didik setelah melakukan kegiatan belajar. Karena kegiatan belajar merupakan proses, maka prestasi belajar adalah outputnya. Dengan demikian, baik tidaknya prestasi belajar mahasiswa, tentunya sangat ditentukan oleh baik tidaknya proses belajar yang dilakukannya (Ilyas, 2008).

Di Perguruan Tinggi, prestasi belajar mahasiswa diukur melalui Indeks Prestasi (IP) yang diperolehnya setiap semester. Skala pengukuran tidak lagi menggunakan angka 0 sampai 100. Tetapi dinyatakan dengan skala 0 sampai 4. Dimana 0 menunjukkan IP terendah, sedangkan 4 menunjukkan IP tertinggi.

Banyak faktor yang berpengaruh terhadap prestasi belajar. Menurut Slameto (2010), terdapat dua faktor yang mempengaruhi belajar yaitu faktor internal dan faktor eksternal. Faktor internal antara lain kondisi fisik, intelegensia, sikap, bakat, minat dan motivasi dalam diri mahasiswa. Sedangkan faktor eksternal yang mempengaruhi prestasi belajar antara lain lingkungan keluarga, lingkungan kampus dan lingkungan masyarakat.

Dalam sistem pendidikan jarak jauh sebagaimana di terapkan di Universitas
Terbuka (UT), sebenarnya faktor internal sangat menentukan prestasi belajar mahasiswa. Terutama motivasi dalam belajar. Karena dalam sistem belajar jarak jauh sangat dituntut kemandirian mahasiswa.

UT sebagai penyelenggara pendidikan jarak jauh telah menyediakan berbagi sumber belajar untuk memudahkan mahasiswa dalam mengaksesnya. Sumber belajar utamanya adalah modul yang telah disediakan secara khusus untuk dapat dipelajari dengan mudah oleh mahasiswa. Selain menggunakan modul yang disediakan oleh UT, mahasiswa juga dapat mengambil inisiatif untuk memanfaatkan perpustakaan, mengikuti tutorial tatap muka atau tutorial melalui internet, siaran radio atau televisi, atau menggunakan bahan ajar berbantuan komputer dan audio/video. Ketika dihadapkan dengan kesulitan dalam belajar, siswa dapat meminta bantuan tutorial di kantor Unit Program Belajar Jarak Jauh Universitas Terbuka (UPBJJ-UT) yang didirikan oleh UT di seluruh daerah di Indonesia (Hendrayana dkk, 2014) .

Namun dalam prakteknya, kemampuan belajar mandiri mahasiswa UT belum sepenuhnya sebagaimana diharapkan. Penelitian Darmayanti (2005) menunjukkan bahwa mahasiswa pendidikan jarak jauh 
masih membutuhkan bantuan institusi untuk meningkatkan kemampuan belajar mandiri mereka. Dalam hal ini adalah dalam bentuk bantuan belajar yakni tutorial, dimana tutor dapat berfungsi sebagai fasilitator dan motivator bagi mahasiswa. Aapalagi bagi mahasiswa frash graduate UT yang sebagaian besar baru tamat Sekolah Menegah Atas (SLTA) dan melanjutkan di UT. Kebiasaan saat STLA yang selalu dikontrol dan selalu dalam pengawasan guru dalam proses belajar, tentunya sangat awam dengan konsep belajar mandiri yang lebih tepat diterapkan pada pembelajaran orang dewasa.

Hal ini juga dialami oleh mahasiswa di UPBJJ-UT Ternate yang merupakan mahasiswa beasiswa Bidikmisi dan CSR. Dimana kemampuan belajar mandiri yang masih minim, menyebabkan kesulitan dalam belajar. Dampaknya tentu pada rendahnya IPK mereka.

Untuk itu, dalam penelitian ini, peneliti ingin menitik beratkan penelitian pada faktor eksternal yang dapat berpengaruh terhadap prestasi belajar mahasiswa Bidikmisi dan CSR UT di UPBJJ-UT Ternate. Adapun faktor ekternal yang menjadi fokus penelitian adalah peran orang tua, peran tutor dan teman kelas sebagai faktor motivasi eksternal yang mendukung prestasi belajar mahasiswa. Orang tua tentunya sangat berperan dalam memberikan motivasi belajar bagi anaknya. Sementara tutor merupakan fasilitator dan motivator yang dapat dimintakan bantuannya oleh mahasiswa untuk mengatasi masalahnya dalam belajar. Sedangkan teman sekelas, dimana dalam keseharian mahasiswa selalu berinteraksi dengannya tentunya akan memberikan dampak dalam proses belajar. Jika teman yang dipilih merupakan teman yang mampu memberikan motivasi, saling mengajak untuk berdiskusi menyelesaikan tugas kuliah dan mampu memberikan solusi dalam belajar, maka tentu akan berdampak baik dalam proses belajar mahasiswa. Demikian pula sebaliknya, jika pertemanan lebih mengarah pada kegiatan negative yang tidak mendukung kegiatan belajar, maka hasilnya pun akan berdampak negative pada prestasi belajar mahasiswa. METODE PENELITIAN
Desain penelitian ini termasuk confirmatory study yang bertujuan untuk menguji hipotesis. Dimana landasan teori yang digunakan sudah terbentuk, hanya diuji kembali apakah teori tersebut dapat dibenarkan. Hasil penelitian dideskripsikan secara kuantitatif dalam bentuk angka-angka disertai dengan penjelasannya (Sugiyono, 2010). Pada penelitian ini yang diuji adalah pengaruh faktor motivasi eksternal yang terdiri dari peran dari orang tua (X1), Peran tutor (X2), serta Peran teman sekelas (X3) terhadap prestasi belajar (Y) mahasiswa penerima beasiswa bidikmisi dan CSR di UPBJJ-UT Ternate.

Populasi dalam penelitian ini adalah seluruh mahasiswa penerima beasiswa bidikmisi dan CSR di UPBJJ-UT Ternate sebanyak 44 mahasiswa. Karena populasi kurang dari 100, maka metode pengambilan sampel menggunakan total sampling, dimana seluruh populasi menjadi sampel penelitian (Sugiyono, 2010).

Semua data penelitian dikumpulkan melalui kuisioner yang disebarkan ke seluruh responden. Sebelum disebarkan, kuisioner terlebih dahulu dilakukan uji coba ke non responden dan diuji validitas sehingga dapat mengukur derajat ketepatan atau kecermatan terhadap instrument yang digunakan. Setelah itu dilakukan uji reliabilitas untuk mengetahui akurasi datanya. Sebelum dilakukan uji hipotesis menggunakan analisis regresi, data yang diperoleh terlebih dahulu diuji dengan menggunakan uji Normalitas dan uji Multikolinearitas, untuk mengetahui kenormalan data dan korelasinya, sebagai syarat untuk dilakukan analisis regresi.

Tahap akhir analisis, dilakukan uji hipotesis penelitian, dengan menggunakan analisis regresi berganda untuk mengetahui pengaruh masing-masing variabel independent $(\mathrm{X})$ terhadap variabel dependent (Y) (Sugiyono, 2010).

\section{HASIL DAN PEMBAHASAN}

\section{Hasil Penelitian}

1. Deskripsi Data Penelitian

a. Distribusi data Variabel Prestasi

\section{Belajar Mahasiswa}

Berdasarkan data Indeks Prestasi Kumulatif (IPK) yang diolah menggunakan 
software program PASW Statistics versi 1. Mahasiswa penerima beasiswa bidikmisi dan CSR memperoleh nilai IPK tertinggi 3, terendah 1 serta rerata (mean) sebesar 1,98; nilai tengah (median) sebesar 2,00; modus (mode) sebesar 2; dan standar deviasi sebesar 0,55 . Berikut ini adalah tabel 1 distribusi frekuensi variabel prestasi belajar.

Tabel 1. Distribusi Frekuensi Variabel Prestasi Belajar

\begin{tabular}{|c|c|c|c|c|c|}
\hline \multicolumn{6}{|c|}{ Prestasi_Y } \\
\hline & & $\begin{array}{c}\text { Frequenc } \\
\mathrm{y} \\
\end{array}$ & Percent & $\begin{array}{c}\text { Valid } \\
\text { Percent }\end{array}$ & $\begin{array}{c}\text { Cumulative } \\
\text { Percent }\end{array}$ \\
\hline \multirow[t]{4}{*}{ Valid } & 1 & 7 & 15.9 & 15.9 & 15.9 \\
\hline & 2 & 31 & 70.5 & 70.5 & 86.4 \\
\hline & 3 & 6 & 13.6 & 13.6 & 100.0 \\
\hline & Total & 44 & 100.0 & 100.0 & \\
\hline
\end{tabular}

Sumber: Data Primer yang diolah

Data tersebut kemudian digolongkan ke dalam kategori kecenderungan prestasi belajar pada 44 responden. Untuk mengetahui kecenderungan masing-masing skor variabel digunakan skor ideal dari subjek penelitian sebagai kriteria perbandingan. Berdasarkan harga skor ideal tersebut dikategorikan berdasar empat kategori kecenderungan normal (Mardapi, 2008), yaitu sebagai berikut:

Tinggi $=(\mathrm{M}+1 \mathrm{SD})$ ke atas

Cukup $=$ M sampai dengan $(M+1 S D)$

Kurang $=(\mathbf{M}-1 \mathrm{SD})$ sampai $\mathrm{M}$

Rendah $=(\mathrm{M}-1 \mathrm{SD})$ ke bawah

Perbandingan rerata observasi dengan rerata skor ideal dapat digunakan untuk mengetahui kecenderungan skor variabel yang dimaksud. Data yang diperoleh dapat diklasifikasikan menjadi empat tingkat kategori sarana pembelajaran yaitu, tinggi, cukup, kurang, rendah dengan perhitungan nilai Mean ideal $(\mathrm{Mi})=1 / 2$ Mahasiswa dibagi menjadi 4 (empat) kecenderungan yaitu tinggi, cukup, kurang, dan rendah. Berdasarkan klarifikasi kecenderungan variabel prestasi belajar dibuat distribusi kecenderungan yang disajikan dalam tabel 2 di bawah ini :

$\mathrm{M}+1 \mathrm{SD}=1,98+0,55=2,53$

$\mathrm{M}-1 \mathrm{SD}=1,98-0,55=1,43$
Tabel 2. Katagori Kecenderungan Variabel Prestasi Belajar

\begin{tabular}{|c|c|c|c|}
\hline Skor & Frekuensi & Presentase (\%) & Katagori \\
\hline$>2,53$ & 2 & 5 & Tinggi \\
\hline $2-2,50$ & 15 & 34 & Cukup \\
\hline $1,5-1,99$ & 20 & 45 & Kurang \\
\hline$<1,45$ & 7 & 16 & Rendah \\
\hline Jumlah & 44 & 100 & \\
\hline
\end{tabular}

Sumber: Data Primer yang diolah

b. Distribusi data Variabel peran Orang Tua dalam Memberikan Motivasi Eksternal

Variabel peran orang tua sebagai faktor motivasi eksternal yang mempengaruhi prestasi belajar, memperoleh skor tertinggi 106 dan terendah 87. Sementara hasil analisisnya diperoleh rerata (mean) 97,09; nilai tengah (median) sebesar 98,00; dan standar deviasi sebesar 4,18.

Rentang data adalah nilai tertinggi dikurangi nilai terendah $(106-87=19)$. Panjang kelas didapat dari rentang dibagi dengan jumlah kelas $(19: 6=3,2)$ dibulatkan menjadi 3.

Tabel 3. Distribusi Frekuensi Variabel Peran Orang Tua

\begin{tabular}{|c|c|c|c|}
\hline No & Interval & Frekuensi & $\begin{array}{c}\text { Persentase } \\
(\boldsymbol{\%})\end{array}$ \\
\hline 1 & $87-90$ & 2 & 4,5 \\
\hline 2 & $91-93$ & 7 & 15,9 \\
\hline 3 & $94-97$ & 11 & 25.0 \\
\hline 4 & $98-101$ & 19 & 43,1 \\
\hline 5 & $102-105$ & 4 & 9,2 \\
\hline 6 & $106-109$ & 1 & 2,3 \\
\hline \multicolumn{2}{|c|}{ Jumlah Total } & 44 & 100 \\
\hline
\end{tabular}

Sumber: Data Primer yang diolah

Berdasarkan

klarifikasi

kecenderungan variabel peran orang tua dibuat distribusi kecenderungan yang disajikan dalam tabel 4 di bawah ini :

$M+1 S D=97,09+4,19=101,28$

$\mathrm{M}-1 \mathrm{SD}=97,09-4,19=92.9$

Tabel 4. Katagori Kecenderungan Variabel Peran Orang Tua

\begin{tabular}{|c|c|c|c|}
\hline Skor & Frekuensi & Presentase (\%) & Katagori \\
\hline $101,28>$ & 8 & 18 & Tinggi \\
\hline $97-100$ & 18 & 41 & Cukup \\
\hline $93-96$ & 13 & 30 & Kurang \\
\hline$<92,9$ & 5 & 11 & Rendah \\
\hline Jumlah & 44 & 100 & \\
\hline
\end{tabular}

Sumber: Data Primer yang diolah 


\section{c. Distribusi data Variabel Peran Tutor sebagai Motivator}

Variabel peran tutor dalam memberikan motivasi sebagai faktor motivasi ekternal yang mempengaruhi prestasi belajar, memperoleh skor tertinggi 58 dan terendah 36. Sementara hasil analisisnya diperoleh rerata (mean) 47,55; nilai tengah (median) sebesar 47,50; dan standar deviasi sebesar 4,91 .

Rentang data adalah nilai tertinggi dikurangi nilai terendah $(58-36=22$. Panjang kelas didapat dari rentang dibagi dengan jumlah kelas $(22: 6=3,66)$ dibulatkan menjadi 4.

Tabel 5. Distribusi Frekuensi Variabel peranan Tutor

\begin{tabular}{|c|c|c|c|}
\hline No & Interval & Frekuensi & $\begin{array}{c}\text { Persentase } \\
(\%)\end{array}$ \\
\hline 1 & $36-39$ & 2 & 4 \\
\hline 2 & $40-43$ & 7 & 16 \\
\hline 3 & $44-47$ & 13 & 30 \\
\hline 4 & $48-51$ & 11 & 25 \\
\hline 5 & $52-55$ & 9 & 20 \\
\hline 6 & $56-59$ & 2 & 5 \\
\hline \multicolumn{2}{|c|}{ Jumlah Total } & 44 & 100 \\
\hline
\end{tabular}

Sumber: Data Primer yang diolah

Berdasarkan

klarifikasi

kecenderungan variabel peran tutor dibuat distribusi kecenderungan yang disajikan dalam tabel 6 di bawah ini :

$\mathrm{M}+1 \mathrm{SD}=47,55+4,91=52,46$

$\mathrm{M}-1 \mathrm{SD}=47,55-4,91=42.64$

Tabel 6. Katagori Kecenderungan Variabel Peran Tutor

\begin{tabular}{|c|c|c|c|}
\hline Skor & Frekuensi & Presentase (\%) & Katagori \\
\hline $52,46>$ & 11 & 25 & Tinggi \\
\hline $48-51$ & 11 & 25 & Cukup \\
\hline $43-47$ & 18 & 41 & Kurang \\
\hline$<42,64$ & 4 & 9 & Rendah \\
\hline Jumlah & 44 & 100 & \\
\hline
\end{tabular}

Sumber: Data Primer yang diolah

\section{d. Distribusi data Variabel Peran Teman Sekelas}

Variabel peran teman sekelas sebagai faktor motivasi eksternal yang mempengaruhi prestasi belajar, memperoleh skor tertinggi 55 dan terendah 38. Sementara hasil analisisnya diperoleh rerata (mean) 48,14; nilai tengah (median) sebesar 49,00; dan standar deviasi sebesar 4,15.

Rentang data adalah nilai tertinggi dikurangi nilai terendah $(55-38=17$. Panjang kelas didapat dari rentang dibagi dengan jumlah kelas $(17: 6=2,83)$ dibulatkan menjadi 3.

Tabel 7. Distribusi Frekuensi Variabel Peran Teman Sekelas

\begin{tabular}{|c|c|c|c|}
\hline No & Interval & Frekuensi & $\begin{array}{c}\text { Persentase } \\
(\%)\end{array}$ \\
\hline 1 & $38-40$ & 3 & 6,8 \\
\hline 2 & $41-43$ & 4 & 9,1 \\
\hline 3 & $44-46$ & 4 & 9,1 \\
\hline 4 & $47-49$ & 16 & 36,4 \\
\hline 5 & $50-52$ & 13 & 29,5 \\
\hline 6 & $53-55$ & 4 & 0 \\
\hline \multicolumn{2}{|c|}{ Jumlah Total } & 44 & 100 \\
\hline
\end{tabular}

Sumber: Data Primer yang diolah

Berdasarkan

klarifikasi

kecenderungan variabel peran teman sekelas dibuat distribusi kecenderungan yang disajikan dalam tabel 8 di bawah ini :

$\mathrm{M}+1 \mathrm{SD}=48,14+4,15=52,29$

$\mathrm{M}-1 \mathrm{SD}=48,14-4,15=43.99$

Tabel 8. Katagori Kecenderungan Variabel Peran Teman Sekelas

\begin{tabular}{|c|c|c|c|}
\hline Skor & Frekuensi & Presentase (\%) & Katagori \\
\hline $52,29>$ & 10 & 23 & Tinggi \\
\hline $48-51$ & 19 & 43 & Cukup \\
\hline $44-47$ & 8 & 18 & Kurang \\
\hline$<43,99$ & 7 & 16 & Rendah \\
\hline Jumlah & 44 & 100 & \\
\hline
\end{tabular}

Sumber: Data Primer yang diolah

\section{Pengujian Prasyarat Analisis}

a. Uji Nomalitas

Syarat suatu data berdistribusi normal jika probabilitasnya (nilai sig) $>0,05$ dan jika probabilitasnya (nilai Sig) $<0,05$ maka data residualnya tidak berdistribusi normal. Untuk mempermudah dalam proses pengolahan data, digunakan software program PASW Statistics versi 18 , berikut ini disajikan table 9 hasil uji normalitas data dengan uji kolmogrofsmirnov.

Tabel 9. One-Sample Kolmogorov-Smirnov Test

\begin{tabular}{|ll|r|}
\hline & & $\begin{array}{c}\text { Unstandardize } \\
\mathrm{d} \text { Residual }\end{array}$ \\
\hline $\mathrm{N}$ & & 44 \\
\hline \multirow{2}{*}{ Nomal Parameters ${ }^{\text {at }}$} & Mean & .0000000 \\
\cline { 2 - 3 } & Std. Deviation & .44200106 \\
\hline sst Extreme & Absolute & .061 \\
\cline { 2 - 3 } Differences & Positive & .061 \\
\cline { 2 - 3 } & Negative & -055 \\
\hline Kolmogorov-Smimov Z & .402 \\
\hline Asymp. Sig. (2-tailed) & .997 \\
\hline
\end{tabular}

a. Test distribution is Normal.

b. Calculated from data. 
Pada table di atas membuktikan bahwa nilai sig 0,997 >0,05 sehingga terbukti data residual berdistribusi normal. Selain itu juga dapat diamati dengan melihat grafik histogram residual atau normal probability plots. Jika data menyebar di sekitar garis diagonal maka data tersebut berdistribusi normal, sehingga dapat dikatakan regresi linear berganda memenuhi asumsi normalitas. Seperti Nampak pada gambar 1 di bawah ini.

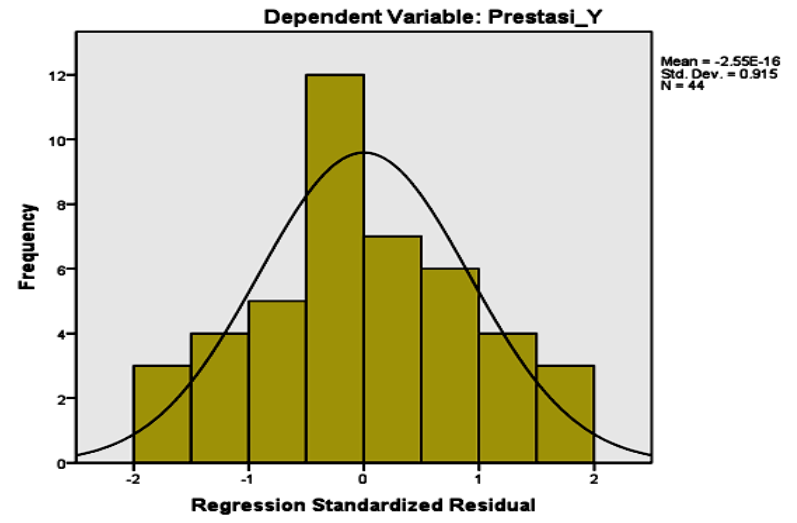

Gambar 1. Grafik Histogram Residual

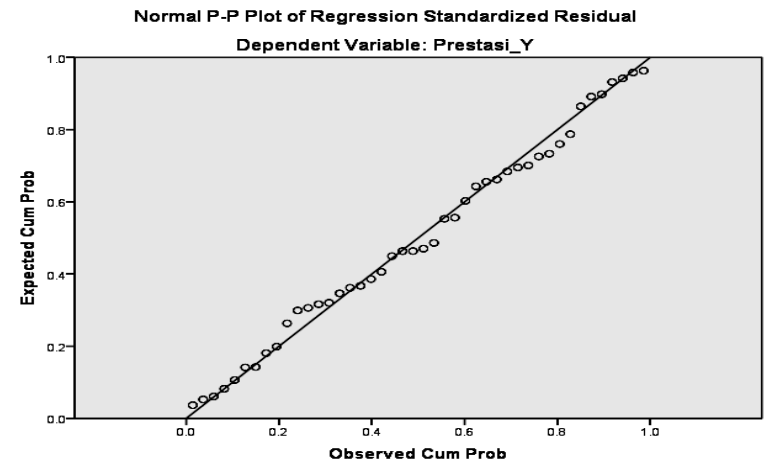

Gambar 2. Grafik Normal P-P Plot

Gambar grafik histogram dan P-P Plot di atas menjelaskan bahwa tampak data menyebar di sekitas garis diagonal yang berarti data berdistribusi normal. Dengan demikian model regresi linear berganda untuk kedua sumber data yaitu data penelitian yang memenuhi asumsi normalitas.

\section{b. Uji Multikolinearitas}

Untuk memastikan model regresi tidak mengalami masalah multikolinearitas atau dapat dikatakan ada korelasi antar variabel bebasnya, maka dilakukan uji Multikolineritas. Dimana jika nilai VIF kurang dari 10 dan atau nilai tolerance lebih dari 0,01 maka dapat disimpulkan dengan tegas bahwa tidak terdapat masalah multikolinearitas. Nilai ini dapat dilihat pada bagian Collinearity Statistics yang dihasilkan dari pengolahan data dengan software program PASW Statistics versi 18 pada table 10 sebagai berikut:

Tabel 10. Nilai Tolerance \& VIF

\begin{tabular}{|c|c|c|}
\hline \multicolumn{3}{|c|}{ Coefficients ${ }^{\mathbf{a}}$} \\
\hline \multirow[t]{2}{*}{ Model } & \multicolumn{2}{|c|}{$\begin{array}{c}\text { Collinearity } \\
\text { Statistics }\end{array}$} \\
\hline & Tolerance & VIF \\
\hline Peran_ORT_X1 & .849 & 1.177 \\
\hline Peran TR X2 & .429 & 2.331 \\
\hline Peran_TS_X3 & .702 & 1.425 \\
\hline
\end{tabular}

a. Dependent Variable: Prestasi Y

Berdasarkan table di atas dapat dideskripsikan bahwa nilai tolerance masingmasing variabel lebih besar dari 0,01 dan nilai VIF kurang dari 10 maka dapat disimpulkan dengan tegas bahwa tidak terdapat masalah multikolinearitas atau model regresi tidak mengalami masalah multikolinearitas.

\section{Uji Hipotesis}

Dengan menggunakan bantuan software program PASW Statistics versi 18, maka diperoleh hasil analisis regresi berganda yang diuraian di bawah ini.

\section{Tabel 11. Ringkasan Hasil Pengujian Hipotesis}

Coefficients $^{2}$

\begin{tabular}{|c|c|c|c|c|c|}
\hline \multirow[t]{2}{*}{ Model } & \multicolumn{2}{|c|}{$\begin{array}{l}\text { Unstandardized } \\
\text { Coefficients }\end{array}$} & \multirow{2}{*}{\begin{tabular}{|c|}
$\begin{array}{c}\text { Standardized } \\
\text { Coefficients }\end{array}$ \\
Beta \\
\end{tabular}} & \multirow[b]{2}{*}{$t$} & \multirow[b]{2}{*}{ Sig. } \\
\hline & B & Std. Error & & & \\
\hline 1 (Constant) & 1.223 & 2.628 & & .465 & .644 \\
\hline Motivasi dari Orang Tua Xl & .006 & .019 & .043 & .295 & .770 \\
\hline Motivasi dari Tutor_X2 & .031 & .023 & .278 & 2.356 & .039 \\
\hline Motivasi dari Teman Sekelas X3 & .022 & .021 & -168 & -2.053 & .042 \\
\hline
\end{tabular}

a. Dependent Variable: Prestasi_Y

- Nilai Sig. 0,770 lebih besar dari 0,05 dan $t_{\text {hitung }} 0,295$ lebih kecil dari $t_{\text {tabel }} 2,028$ yang berarti bahwa tidak terdapat pengaruh yang positif antara peran orang tua dalam memberikan motivasi terhadap prestasi belajar mahasiswa penerima 
beasiswa bidikmisi dan CSR di UPBJJUT Ternate.

- Nilai Sig. 0,039 lebih kecil dari 0,05 dan $t_{\text {hitung }} 2,356$ lebih besar dari $t_{\text {tabel }} 2,028$ yang berarti bahwa terdapat pengaruh yang positif dan signifikan antara peran tutor dalam memberikan motivasi terhadap prestasi belajar mahasiswa penerima beasiswa bidikmisi dan CSR di UPBJJ-UT Ternate.

- Nilai Sig. 0,042 lebih kecil dari 0,05 dan $t_{\text {hitung }}-2,053$ lebih besar dari $t_{\text {tabel }}-2,028$ yang berarti bahwa terdapat pengaruh yang negatif antara peran teman sekelas terhadap prestasi belajar mahasiswa penerima beasiswa bidikmisi dan CSR di UPBJJ-UT Ternate.

\section{PEMBAHASAN}

1. Pengaruh Peran Orang Tua sebagai Faktor Motivasi Ekternal Terhadap Prestasi Belajar Mahasiswa

Hasil penelitian menunjukkan bahwa tidak terdapat pengaruh yang signifikan dari peran orang tua dalam memberikan motivasi terhadap prestasi belajar mahasiswa penerima beasiswa Bidikmisi dan CSR UT di UPBJJUT Ternate.

Hasil penelitian ini tidak sejalan dengan penelitian-penelitian yang lain yang mengusung variabel peran orang tua terhadap prestasi belajar anak. Diantaranya yaitu penelitian Nugraheni (2014) yang melakukan penelitian pada siswa kelas III SD di Sinduharjo Sleman yang menunjukkan hasil bahwa ada pengaruh yang signifikan peran orang tua terhadap prestasi belajar siswa. Demikian juga hasil penelitian Ningsih (2016) menunjukkan bahwa orang tua yang memiliki perhatian pada anak semakin meningkatkan prestasi belajar siswa. Untuk itu, peranan orangtua sangat menentukan dalam mendukung pencapaian prestasi belajar anak dengan cara mendidik, membimbing, memotivasi dan memfasilitasi belajar anak secara berkelanjutan (Arifin, 1992).

Adanya perbedaan antara hasil penelitian ini dengan penelitian-penelitian yang telah diuraikan di atas, menurut peneliti dapat terjadi, karena disebebkan dalam penelitian ini responden penelitian adalah para mahasiswa. Sementara kedua penelitian sebelumnya Nugraheni (2014) dan Ningsih (2016) sampel penelitian adalah siswa yang usianya masih di bawah 18 tahun, sehingga masih dibutuhkan perhatian dan arahan orang tua dalam belajar. Rata-rata anak usia sekolah (siswa) juga masih tinggal bersama orang tuanya sehingga masih mudah dikotrol oleh orang tua. Sementara mahasiswa, saat kuliah sebagian besar tidak lagi tinggal dengan orang tuanya (kos). Hal ini juga terjadi dengan mahasiswa Bidikmisi dan CSR di UPBJJ-UT Ternate yang rata-rata berasal dari luar Kota Ternate, sehingga otomatis saat kuliah berpisah dengan orang tua.

Namun demikian, alasan ini tidak sepenuhnya diterima. Sebab walaupun adanya keterpisahan jarak, sebagai bentuk tanggung jawab, orang tua dapat memberikan motivasi bagi anak melalui komunikasi telepon. Melalui komunikasi tersebut, orang tua dapat memberikan dorongan tentang pentingnya belajar dengan tujuan dapat meningkatkan prestasi belajar, sehingga anak benar-benar merasa penting dan membutuhkan apa yang dianjurkan oleh orangtuanya (Sucipto, 2000). Menurut Schunk (2010), orang tua yang memiliki wawasan, pengetahuan serta pengalaman yang tinggi akan lebih mudah memberikan motivasi yang positif untuk anaknya.

\section{Pengaruh Peran Tutor sebagai Faktor Motivasi Ekternal Terhadap Prestasi Belajar Mahasiswa}

Tuntutan terhadap kemampuan belajar mandiri menjadi suatu konsekuensi bagi mahasiswa dalam sistem pendidikan jarak jauh. Kemampuan belajar mandiri dibutuhkan mahasiswa pendidikan jarak jauh karena sistem belajar jarak jauh memisahkan mahasiswa dengan pengajar (dosen) secara fisik. Kondisi tersebut membuat mahasiswa pendidikan jarak jauh harus memerankan beberapa fungsi pengajar, termasuk memberi motivasi pada dirinya dan mencari informasi untuk kebutuhan belajarnya (Tri Darmayanti, 2005).

Rujukan utama mahasiswa dalam belajar adalah Modul. Dimana dalam sistem belajar jarak jauh, semua materi telah disediakan oleh dosen secara tertulis di dalam modul tiap matakuliah. Selain modul juga 
disediakan berbagai layanan bantuan belajar, agar mahasiswa dapat mengakses layanan bantuan belajar tersebut. Salah satunya yakni Tutorial yang dapat diikuti oleh mahasiswa secara tatap muka atau online. Dalam kegiatan tutorial, mahasiswa akan didampingi oleh tutor yang berfungsi sebagai fasilitator yang membantu mahasiswa dalam mengatasi masalah belajarnya sekaligus berfungsi sebagai motivator bagi mahasiswa untuk belajar secara mandiri, sehingga mampu menguasai kompetensi tiap matakuliah.

Dalam penelitian ini menunjukkan bahwa terdapat pengaruh positif dan signifikan dari peran tutor dalam memberikan motivasi terhadap prestasi belajar mahasiswa penerima beasiswa Bidikmisi dan CSR UT di UPBJJ-UT Ternate. Ini membuktikan bahwa walaupun dalam sistem belajar jarak jauh, mahasiswa dituntut untuk mampu belajar mandiri, namun untuk mahasiswa yang fresh graduate (baru tamat SLTA) sebagaimana mahasiswa beasiswa Bidikmisi dan CSR UT, masih membutuhkan pendampingan dari tutor. Wajar, sebab mereka belum lama lulus sekolah, dimana budaya belajar di sekolah mereka masih dengan sistem tatap muka yang proses belajarnya selalu didampingi oleh guru sebagai sumber belajar. Ketika mereka telah melanjutkan kuliah di UT, maka tutorlah menjadi salah satu tempat mereka bertanya, berdiskusi dan meminta bantuan dalam mengatasi masalah yang dihadapi dalam memahami materi kuliah yang telah disajikan oleh dosen di dalam modul.

Hasil penelitian Waluyo (2015), menunjukkan bahwa untuk mendorong keberhasilan peserta belajar, maka tutor harus mampu berfungsi sebagai Informator, Organisator, Motivator, Director, Inisiator, Fasilitator, Mediator dan Evaluator.

\section{Pengaruh Peran Teman Sekelas sebagai Faktor Motivasi Ekternal Terhadap Prestasi Belajar Mahasiswa}

Hasil penelitian ini menunjukkan bahwa terdapat pengaruh yang negatif antara peran teman sekelas terhadap prestasi belajar mahasiswa penerima beasiswa bidikmisi dan CSR di UPBJJ-UT Ternate. Hasil ini tentunya sangat bertentangan dengan hasil penelitian sebelumnya. Penelitian Astuti (2016), menunjukkan bahwa justru teman Sebaya berpengaruh positif dan signifikan terhadap Prestasi Belajar. Demikian pula, hasil penelitian Saputro dan Pardiman (2012) pada mahasiswa Program Studi Pendidikan Akuntansi Angkatan 2009 Fakultas Ekonomi Universitas Negeri Yogyakarta, menunjukkan bahwa terdapat pengaruh positif dan signifikan lingkungan teman Sebaya terhadap Prestasi Belajar.

Bahkan hasil penelitian Indrianie
(2015) menunjukkan bahwa dalam pembelajaran cooperative learning model tutor sebaya, terbukti memberikan pengaruh signifikan terhadap hasil belajar peserta didik yaitu hasil belajar yang lebih baik. Pada model pembelajar ini, teman di dalam kelas telah mampu menjadi tutor bagi teman sebayanya, sehingga muncul rasa bangga sekaligus saling menghargai dan saling mendukung untuk menciptakan suasana belajar yang aktif.

Namun Ron Herron dan Val J. Peter (2005), mengingatkan bahwa untuk memenuhi kriteria teman yang dapat mendorong prestasi belajar, maka perlu melihat teman yang akan dipilih untuk bergaul. Mencari seorang teman bergaul yang baik seharusnya memilih teman yang memiliki kriteria : dapat membedakan batasbatas pribadi yang meliputi fisik maupun emosional, tidak melakukan kekerasan dan tidak membahayakan orang lain, dapat dipercaya dan tidak iri hati, memiliki prasangka yang baik, bukan seorang pemarah, tidak suka mengolok-olok orang lain, tidak jail, tidak suka menekan dan tidak berbohong dan menipu.

Ketika salah memilih teman maka tentunya akan berdampak negatif terhadap prestasi belajar. Hasil penelitian Murtana (2014), menunjukkan bahwa ada hubungan negatif yang sangat signifikan antara interaksi teman sebaya dengan stres belajar.

Dari penjelasan teori dan hasil penelitian di atas, maka dapat disimpulkan bahwa peran teman sekelas, sebagai bentuk pergaulan di dalam dan di luar kampus memiliki pengaruh yang sangat signifikan terhadap prestasi belajar. Jika kebanyakan teman bergaulnya memiliki karakter serta 
prestasi belajar yang baik, maka berpengaruh kepadanya. Sehingga perlahan-lahan karakter dan prestasinya meningkat menjadi baik. Atau sebaliknya, jika karakter dan prestasi kebanyakan teman bergaulnya buruk akan menular kepadanya, sehingga prestasi belajarnya menurun dan menjadi buruk.

\section{KESIMPULAN}

1. Peran orang tua sebagai faktor motivasi ekternal, tidak berpengaruh signifikan terhadap prestasi belajar mahasiswa penerima beasiswa bidikmisi dan CSR di UPBJJ-UT Ternate. Artinya sekalipun orang tua membina dan membiayai anaknya yang sudah kuliah, namun tidak berpengaruh pada prestasi belajar mahasiswa tersebut, hal ini karena kebanyakan mahasiswa ingin hidup bebas dan lepas dari pengawasan orang tua.

2. Peran tutor sebagai faktor motivasi ekternal, berpengaruh positif dan signifikan terhadap prestasi belajar mahasiswa penerima beasiswa bidikmisi dan CSR di UPBJJ-UT Ternate. Artinya semakin tinggi peran tutor dalam upaya berbagai perbaikan metode, strategi dan model tutorial, maka akan memberikan kontribusi meningkatkan prestasi belajar mahasiswa tersebut.

3. Peran teman sekelas sebagai faktor motivasi ekternal, berpengaruh negatif dan signifikan terhadap prestasi belajar mahasiswa penerima beasiswa bidikmisi dan CSR di UPBJJ-UT Ternate. Artinya semakin besar pengaruh negatif berkontribusi terhadap menurunnya prestasi belajar mahasiswa tersebut.

\section{DAFTAR PUSTAKA}

Arifin (1992) Pokok-pokok Pikiran Tentang Bimbingan dan Penyuluhan Agama. Jakarta: Bulan Bintang

Astuti, Danti I. (2016). Pengaruh Pergaulan Kelompok Teman Sebaya Dan Motivasi Belajar Terhadap Prestasi Belajar Akuntansi Siswa Kelas XI IPS SMA Negeri 1 Parakan Tahun Ajaran 2015/2016. Skripsi. Program Studi Pendidikan Akuntansi, Universitas Negeri Yogyakarta

Darmayanti, Tri (2005). Efektivitas intervensi keterampilan self-regulated learning dan keteladanan dalam meningkatkan kemampuan belajar mandiri dan prestasi belajar mahasiswa pendidikan jarak jauh. Disertasi yang tidak dipublikasikan, Jakarta: Universitas Indonesia.

Hendrayana, Angga S. dkk (2014). Motivasi Belajar, Kemandirian Belajar Dan Prestasi Belajar Mahasiswa Beasiswa Bidikmisi di UPBJJ UT Bandung. Jurnal Pendidikan Terbuka dan Jarak Jauh, Volume 15, Nomor 2, pp. 81-87 Ilyas (2008). Fungsi dan Pengukuran Prestasi Belajar. Yogyakarta : Pustaka Belajar Indrianie, Niken S. (2015). Penerapan Model Tutor Sebaya pada Mata Pelajaran Bahasa Inggris Reported Speech terhadap Hasil Belajar Peserta didik MAN Kota Probolinggo. Jurnal Kebijakan dan Pengembangan Pendidikan, Volume 1, Nomor 1, pp. 126-132

Mardapi, Djemari (2008). Teknik Penyusunan Instrumen Tes dan Non Tes. Yogyakarta : Mitra. Cendikia Prss Murtana, Agus (2014), Hubungan Antara Harga Diri Dan Interaksi Teman Sebaya Dengan Stres Belajar. Tesis. Program Studi Magister Sains Psikologi, Universitas Muhammadiyah Surakarta. http://eprints.ums.ac.id/39224/1/NAS KAH\%20PUBLIKASI.pdf

Ningsih, Rita (2016). Pengaruh Kemandirian Belajar Dan Perhatian Orang Tuaterhadap Prestasi Belajar Matematika. Jurnal Formatif, Volume 6, Nomor 1, pp. 73-84

Nugraheni, Rarastiti K. (2015). Pengaruh Peran Orangtua Motivasi Belajar Danlingkungan Keluargaterhadap Prestasibelajarsiswa Kelas III SD Segugus Sinduharjo Sleman Tahun Ajaran 2014/2015. Repository Universitas PGRI, http://repository.upy.ac.id/138/1/Jurna 1\%20Rarastiti\%20Kusuma\%20Nugrah eni.pdf

Saputro, Singgih T. dan Pardiman (2012). Pengaruh Disiplin Belajar Dan Lingkungan Teman Sebaya Terhadap 
Prestasi Belajar Mahasiswa Program Studi Pendidikan Akuntansi Angkatan 2009 Fakultas Ekonomi Universitas Negeri Yogyakarta. Jurnal Pendidikan Akuntansi Indonesia, Volume $\mathrm{X}$, Nomor 1, pp. 78-97

Schunk, D.H., Pintrich, P.R., \&Meece, J.L., (2010). Motivation in Education: Theory, Research, and Applications Third Edition. New Jersey: Pearson Education.

Slameto (2010). Belajar dan Faktor-Faktor yang Mempengaruhinya. Jakarta : PT. Rineka Cipta

Sucipto dan Raflis (2000), Profesi Keorangtuaan. Jakarta: Rineka Cipta

Waluyo, Yoga T. (2015), Peran Tutor Dalam Meningkatkan Motivasi Belajar Peserta Didik Melalui Pendekatan Andragogi Di Rutan Banjarnegara. Journal of Non Formal Education and Community Empowerment, Volume 4, Nomor 1, pp. 71-78 